\title{
ОЦНЮЮАННЯ ЗАПАСІВ НЕСУЧОЇ ЗДАТНОСТІ КУЗОВІВ ВАНТАЖНОГО ВАГОНОБУДУВАННЯ ТА ЇХ ЕЛЕМЕНТІВ
}

\section{INVENTORY VALUATION TRUCK CARRYING CAPACITY OF BODY CARRIAGE AND THEIR ELEMENTS}

\author{
Представив д-р техн. наук, професор М.В. Паламарчук
}

\begin{abstract}
Постановка проблеми i аналіз результатів останніх досліджень. В сучасних умовах ринкових механізмів господарювання, конкуренції з боку інших видів транспорту перед вітчизняними фахівцями залізничної галузі гостро стоїть проблема створення високоефективного залізничного комплексу, який буде відповідати показникам світового рівня. Створення такого комплексу вимагає вирішення ряду науково-технічних завдань, що визначені у Стратегії розвитку залізничного транспорту на період до 2020 року, яку схвалено розпорядженням Кабінету Міністрів України від 16 грудня 2009 року № 1555-р. Одним із пріоритетних завдань $\epsilon$ розроблення та впровадження у виробництво вітчизняного рухомого складу 3 істотно підвищеними технікоекономічними показники (в тому числі i для забезпечення потреб залізниць України), що обумовлює важливість розгортання науково-дослідних та дослідно-конструкторських робіт, спрямованих на підвищення рівнів проектування, виробництва та експлуатації залізничних транспортних засобів. При
\end{abstract}

цьому переважну більшість рухомого складу залізниць складають вантажні вагони. За оцінками фахівців [1], перспективними завданнями для вагонобудівників та організацій, які експлуатують вантажні вагони, є вирішення задач з удосконалення процедур дослідження та проектування несучих систем їх кузовів. В результаті вирішення зазначених задач можливо буде підвищити рівень ефективності використання металоконструкцій вантажних вагонів (за рахунок визначення та використання відповідних резервів міцності [2]) та визначення їх ресурсу [3] (в тому числі залишкового) з відповідним прогнозуванням.

$\begin{array}{rcr}\text { Мета } & \text { статті та } & \text { викладення } \\ \text { основного } & \text { матеріалу. } & \text { У }\end{array}$
формалізовано процедуру визначення запасів несучої здатності загальних конструкцій кузовів та їх складових елементів вантажних вагонів. Подано приклади застосування запропонованого методу для дослідження несучої здатності елементів кузовів однієї із базових конструкцій універсальних напіввагонів.

При розробці процедури визначення запасів несучої здатності загальних 
конструкцій кузовів та їх складових елементів вантажних вагонів в основу покладено принцип - запас міцності загальних конструкцій/елементів визначається мінімальним запасом міцності їх складових. У загальному випадку відповідну процедуру можна подати у вигляді алгоритму наведеного на рис. 1.

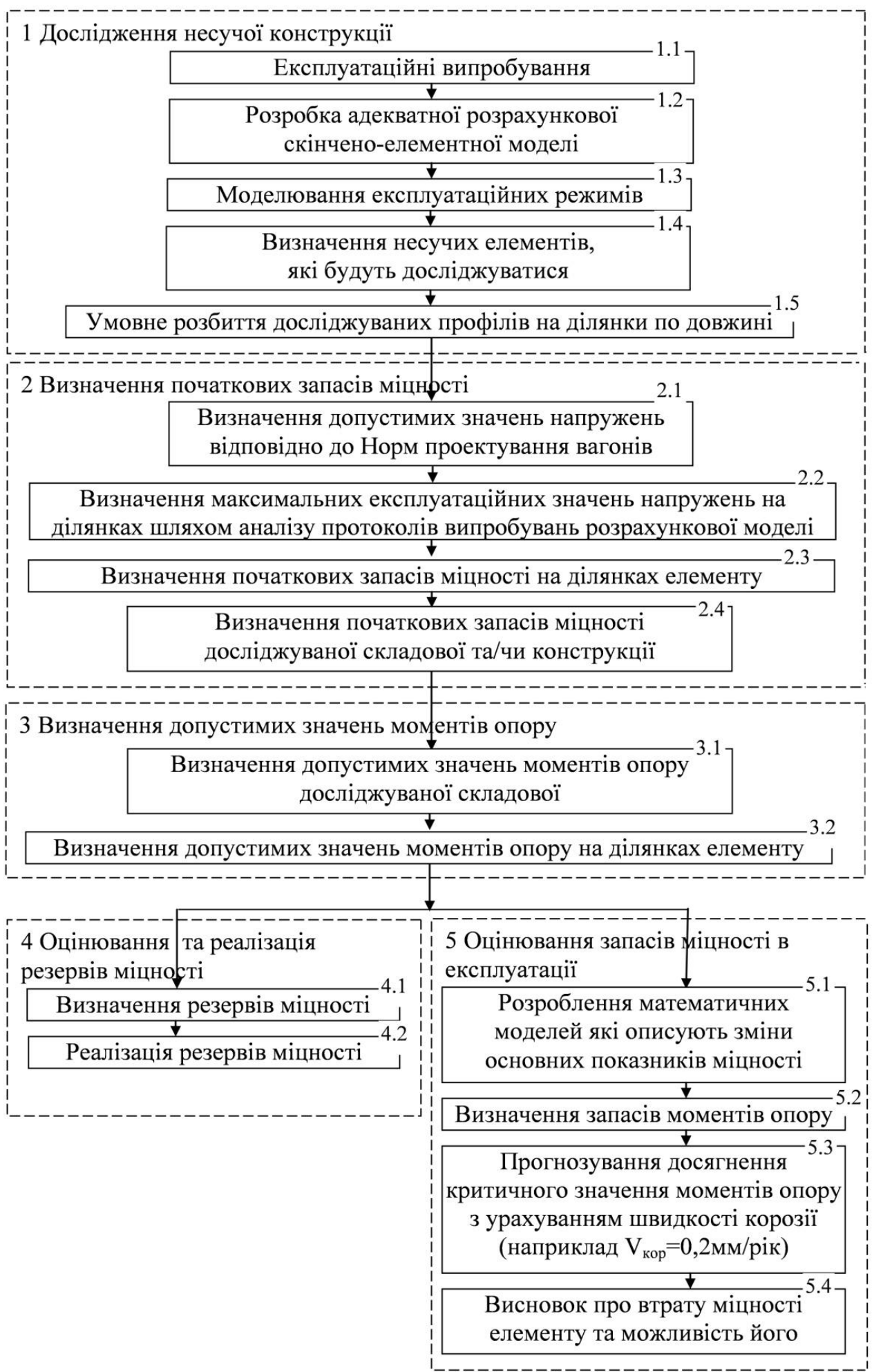

Рис. 1. Алгоритм визначення запасів несучої здатності складових кузовів вантажних вагонів при проектуванні та в експлуатації 
3 рис. 1 видно, що формалізовану процедуру розбито на п'ять основних стадій (блоків), кожен 3 яких включає декілька етапів (кроків). Так, перша стадія візуалізованої на рис. 1 процедури присвячена дослідженню несучої системи конструкції вантажного вагона. При цьому у випадках проведення відповідних робіт для окремих несучих складових вантажних вагонів обов'язково необхідно досліджувати іiі роботу по сприйняттю навантажень у загальній конструкції. На першому етапі проведення дослідницьких робіт передбачено проведення експлуатаційних випробувань натурних зразків досліджуваної конструкції вагонів (у разі попередньо проведених таких робіт достатньо використовувати відповідні протоколи випробувань) 3 метою визначення дійсних значень напружень у відповідних/контрольних точках. На етапі 1.2 розроблюється розрахункова скінченноелементна модель, настроювання працездатності якої проводиться за раніше експериментально отриманими даними. Етап 1.3 включає комп'ютерне моделювання експлуатаційних режимів роботи кузова вантажного вагона (відповідно до [4-6] більше двадцяти випадків) 3 формуванням відповідних протоколів. На наступному етапі визначаються несучі елементи, які будуть досліджуватися (вибір залежить від поставленої мети дослідження). Завершальний етап першого блоку включає роботи з розбиття досліджуваних елементів на окремі ділянки/частини. У зв’язку з тим, що переважна більшість несучих елементів кузовів вантажних вагонів виготовляється 3 прокатних чи подібних до них профілів, на цьому кроці виконуються роботи з розбиття профілів на ділянки ( $\left.l_{k} \in[1: n]\right)$ по довжині. Розмір ділянок (ї кількість n) обирається/змінюється в залежності від необхідної глибини пропрацювання конструкції, більша деталізація (зменшення розмірів окремих ділянок) сприятиме підвищенню точності таких робіт. Друга стадія формалізованої процедури присвячена визначенню початкових (закладених при проектуванні) запасів міцності конструкції. Так, відповідно до [6], на етапі 2.1 передбачено визначення допустимих значень напружень $[\sigma]_{\text {розр.реж. }}$ в залежності від розрахункових режимів досліджуваного експлуатаційного випадку. На 2.2 зі сформованих на попередній стадії протоколів для кожного 3 експлуатаційних режимів визначаються максимальні еквівалентні напруження $\sigma_{\text {експл.випадок }}^{l_{k} \max }$ на виділених раніше ділянках. Далі (етап 2.3) за формулою 1 на окремих ділянках визначаються значення початкових запасів міцності $\gamma_{\text {екслл.випадок та }}^{l_{k}}$ шляхом їх зіставлення обирається найменше 3 них (2). Звичайно, у разі отриманого негативного результату за формулою 1 робиться висновок про невідповідність конструкції нормативним вимогам та проводяться відповідні дії 3 виправлення невідповідностей.

$$
\gamma_{\text {експл.випадок }}^{l_{k}}=\frac{[\sigma]_{\text {розр.реж. }}-\sigma_{\text {експл.випадок }}^{l_{k} \text { тах }}}{[\sigma]_{\text {розр.реж. }}} \cdot 100 \% .
$$

$$
\gamma^{l_{k}}=\min \gamma_{\text {експл.випадок }}^{l_{k}},
$$

де $\gamma^{l_{k}}$ - значення запасу міцності на ділянці $l_{k}, \%$;

$$
\min \gamma_{\text {експл.випадок }}^{l_{k}}-\text { найменше значення }
$$

запасу міцності на ділянці $l_{k}$ серед 
значень, які відповідають всім досліджуваним випадкам, \%.

Потім (крок 2.4) за формулою 3 визначаються початкові запаси міцності досліджуваної складової (конструкції) $\gamma^{\text {скл.(констр.) }}$ шляхом зіставлення та вибору найменшого значення запасу на складових ділянках $\min \gamma^{l_{k}}, \%$.

$$
\gamma^{\text {скл.(констр.) }}=\min \gamma^{l_{k}}
$$

У зв'язку 3 тим, що експлуатаційні

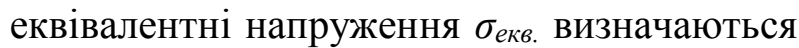
як співвідношення сумарного еквівалентного моменту $\left(M_{\text {екв. }}\right)$ та міцнісних характеристик $\left(W_{X(Y)}\right)$, але при цьому

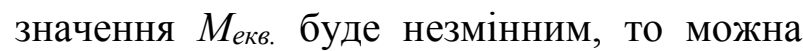
зробити висновок, що величина $\sigma_{\text {екв }}$ буде прямо пропорційно залежати від значень моментів опору $W_{X(Y)}$. Тому як основні міцнісні характеристики профілів можна використовувати моменти опору $W_{X(Y)}$. У зв'язку із зазначеним оцінювання міцнісних якостей несучої здатності складових елементів кузовів вантажного вагонобудування зводиться до оцінювання ïx запасів моментів опору. Для цього на наступній (третій) стадії проводяться роботи 3 визначення допустимих значень моментів опору. Так, визначення допустимих значень моментів опору досліджуваної складової $\left[W_{X(Y)}^{\text {скл. }}\right]$ визначається на етапі 3.1 за формулою 4

$$
\left[W_{X(Y)}^{\text {скл. }}\right]=W_{X(Y)}^{\text {поч. }} \cdot\left(100-\gamma^{\text {скл. }}\right)
$$

де $\left[W_{X(Y)}^{c \kappa л .}\right]$ - допустиме значення моменту опору складової по осі X чи $\mathrm{Y}, \mathrm{cm}^{3}$;

$W_{X(Y)}^{\text {nоч. }} \quad-\quad$ початкове значення (визначається 3 відповідних стандартів
ДСТУ чи ТУ моменту опору по осі Х чи Y, $\mathrm{cm}^{3}$.

На етапі 3.2 визначаються допустимі значення моментів опору на ділянках досліджуваної складової $\left[W_{X(Y)}^{l_{k}}\right]$ за формулою 5

$$
\left[W_{X(Y)}^{l_{k}}\right]=W_{X(Y)}^{\text {nou. }} \cdot\left(100-\gamma^{l_{k}}\right)
$$

Далі, в залежності від поставленого завдання: 1) визначення та використання резервів міцності конструкції чи 2) оцінювання запасів та прогнозування резервів міцності конструкції в експлуатації, обирається відповідно блок 4 чи 5.

Блок 4 включає роботи 3 визначення (етап 4.1) та використання (етап 4.2) резервів міцності. Визначення резервів міцності (для складової $\gamma_{w_{X(Y)}^{\text {ckл. }}}^{\text {ре. }}$ або для окремої iï ділянки складової $\gamma_{w_{X(Y)}^{l_{k}}}^{\text {pes. }}$ ) відбувається як зіставлення допустимих та початкових значень моментів опорів відповідно за формулами 6 та 7:

$$
\begin{aligned}
& \gamma_{W_{X(Y)}^{\text {скле. }}}^{\text {рез. }}=\left|\frac{\left[W_{X(Y)}^{\text {скл. }}\right]-W_{X(Y)}^{\text {поч. }} \mid}{\left[W_{X(Y)}^{\text {склл. }}\right]}\right| \cdot 100 \% .
\end{aligned}
$$

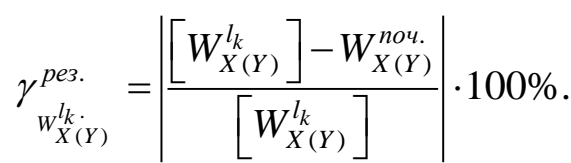

Після чого проводяться роботи 3 реалізації $[2,7]$ виявлених резервів.

У випадку використання поданої формалізованої процедури для оцінювання запасів міцності в експлуатації виконуються дії, зазначені у блоці 5. На першому етапі (5.1) стадії 5 визначаються математичні моделі, які описують зміну основних показників (моментів опору та матеріалоємності) досліджуваних несучих елементів кузовів вагонів від варіювання їх 
геометричних параметрів. Особливості таких робіт подано у статті [8]. Далі (крок 5.2) визначаються за формулами 8 та 9 відповідно конструкційні запаси/резерви міцності для окремих ділянок складової $\gamma_{W_{X(Y)}^{l_{k}}}^{i c н .}$ та її загальне значення $\gamma_{W_{X(Y)}^{i c k l}}^{i c h .}$.

$$
\underset{W_{X(Y)}^{l_{k}}}{\gamma_{\text {k }}^{\text {icr. }}}=\left|\frac{\left[W_{X(Y)}^{l_{k}}\right]-W_{X(Y)}^{i c H .}}{\left[W_{X(Y)}^{l_{k}}\right]}\right| \cdot 100 \% ;
$$

де $W_{X(Y)}^{i c н}$ - значення моменту опору по осі $\mathrm{X}$ чи Ү досліджуваного профілю, см$^{3}$.

$$
\gamma_{W_{X(Y)}^{i c r .}}^{i c \mu .}=\min \gamma_{W_{X(Y)}^{l_{k}}}^{i c \mu .}
$$

де $\min \gamma_{W_{X(Y)}^{3} \tilde{n}_{k} .}^{-}$значення найменшого запасу на складовій ділянці, \%.

Після вищенаведених робіт проводиться прогнозування часу до досягнення критичного значення моменту опору 3 урахуванням швидкості корозії відповідно до $[6,9]$. I на завершальному етапі 5.4 робиться висновок про необхідність відновлення та його обсяги для складової.

$$
\text { Для прикладу }
$$

використання запропонованого методу нижче подано його застосування. Як досліджувані елементи несучої системи вантажних вагонів обрано кузов найбільш розповсюдженого та затребуваного їх типу - універсальних напіввагонів. В рамках зазначених робіт проаналізовано найпоширеніші моделі напіввагонів вагонобудівників країн СНД, серед яких: ВАТ «НПЦ» УралВагонЗавод», ПАТ «Крюківський вагонобудівний завод», ПАТ «Азовмаш», ПАТ «Стахановський вагонобудівний завод», ПАТ «Днепрвагонмаш», ВАТ "Алтайвагон", ПрАТ «ДМЗ», ПАТ «Дизельний завод», ПрАТ «НПЦ «Трансмаш», перепрофільовані ВР3 Укрзалізниці (Дарницький ВР3, ДП «Укрспецвагон», Попаснянський ВР3 та Стрийський ВР3) та інші і визначено найпоширенішу базову конструкцію їх кузовів (рис. 2).

Як складові для дослідження обрано (див. рис. 2) верхній пояс стіни торцевої та вертикальний шворневий стояк стіни бокової, які у даному випадку виконано із профілю вагонного стояка (рис. 3, а) відповідно до ГОСТ 5267.6-90.

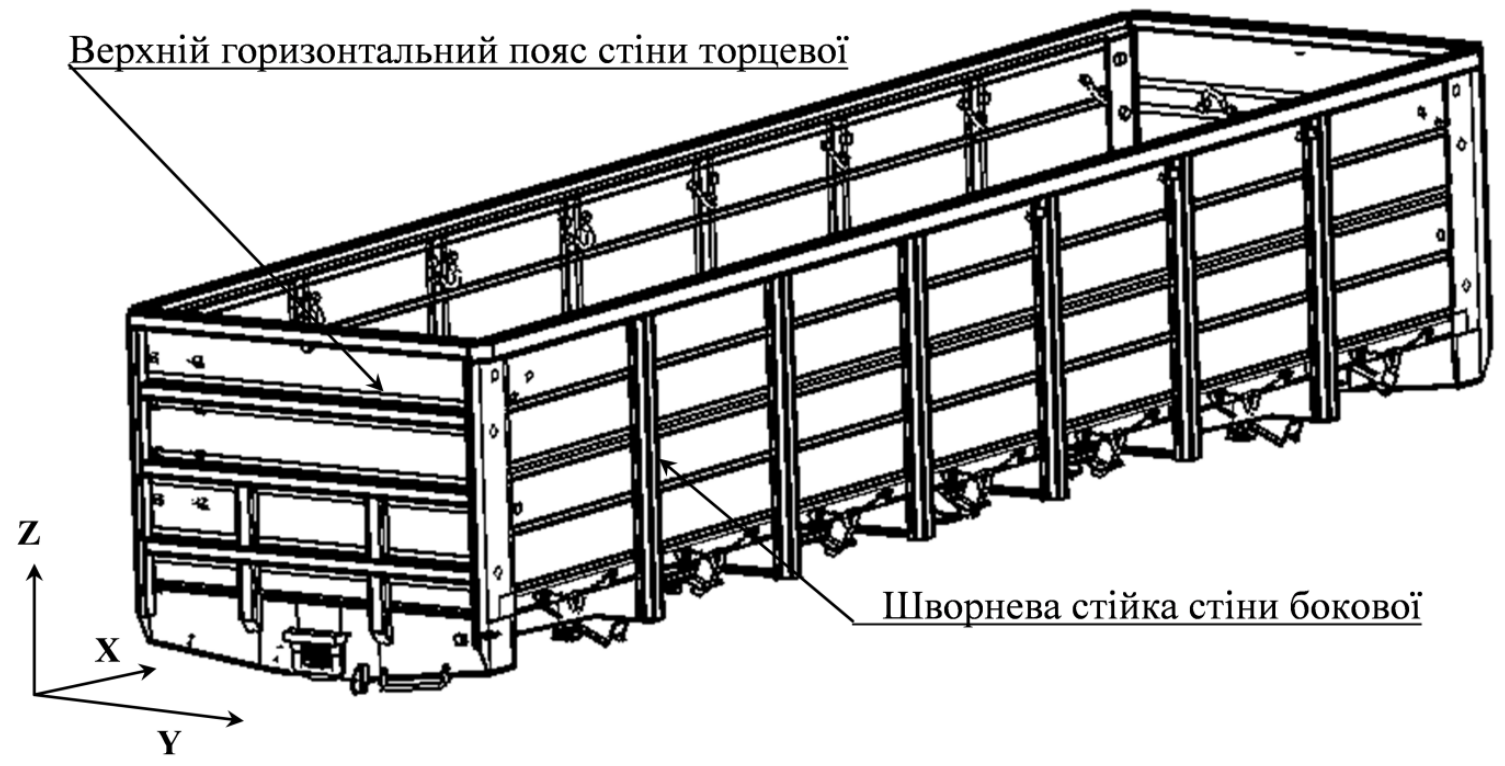

Рис. 2. Загальний вигляд кузова напіввагону 


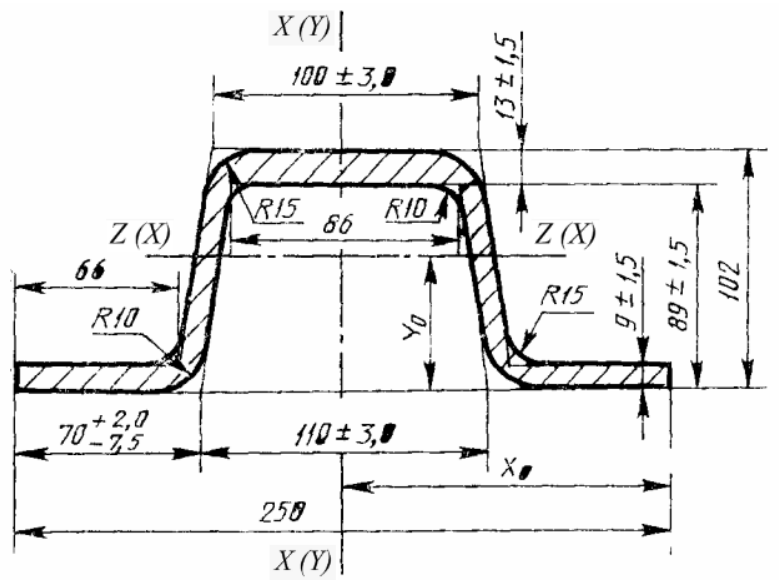

а) відповідно до

ГОСТ 5267.6-90

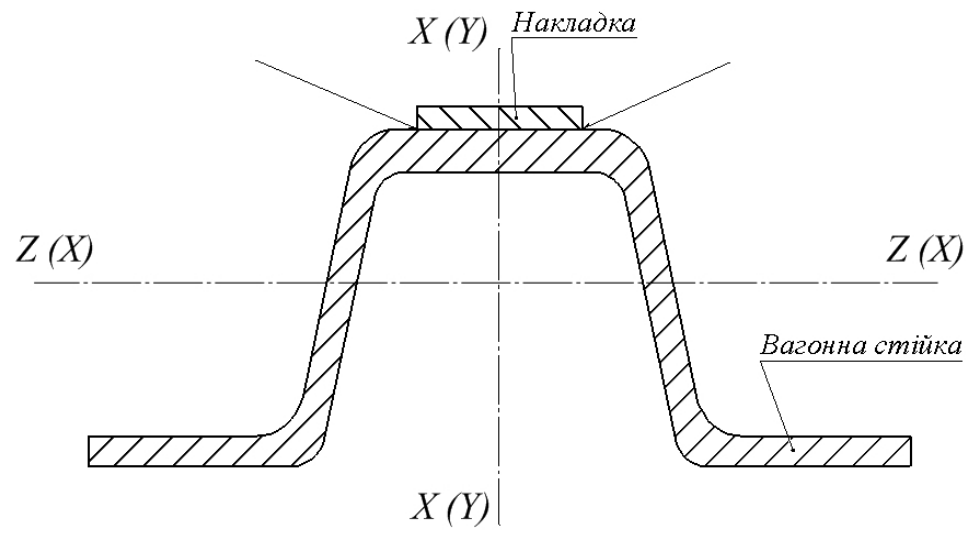

б) 3 накладкою

$7 \mathrm{MM}$

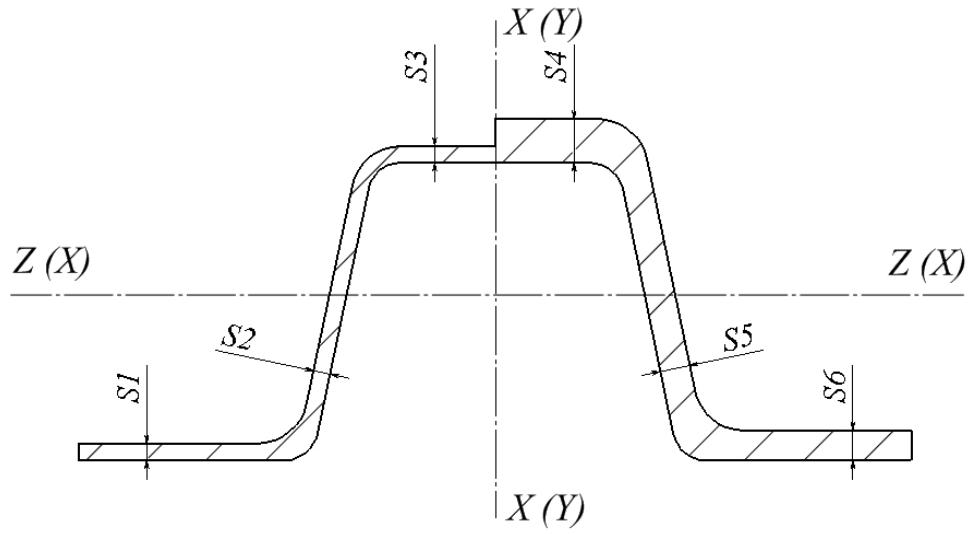

в) 3 імітацією корозійного зносу по ділянках $S 1, S 2$, S3

Рис. 3. Профіль вагонного стояка

За мету проведених досліджень було обрано завдання 3 визначення запасів міцності складової - вагонного стояка, при проведенні робіт 3 підсилення цього профілю накладкою (рис. 3, б) та імітації його корозійного зносу по ділянках $S 1, S 2$, S3 (рис. 3, в). $\begin{array}{rrr}\text { були } & \text { розв'язання } & \text { поставлених задач } \\ \text { броведені } & \text { експлуатаційні }\end{array}$ випробування для відповідних моделей напіввагонів 12-9904 та 12-9904-01 [10]. Після чого змодельовано можливі експлуатаційні випадки (візуалізація особливостей на рис.4) та сформовано відповідні протоколи 3 зазначенням еквівалентних напружень у досліджуваних елементах. 


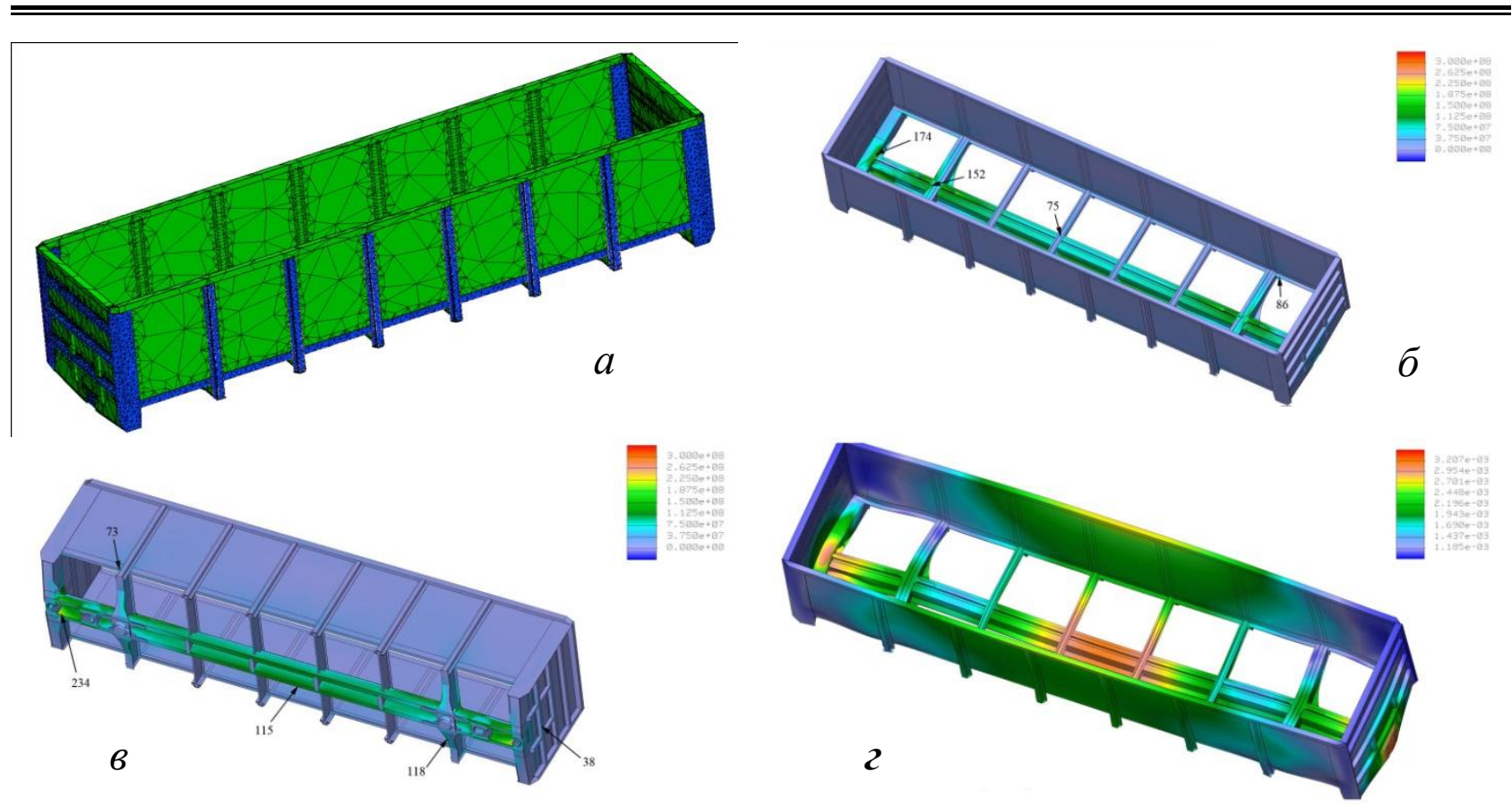

Рис. 4. Розрахункова модель напіввагона:

a) скінченноелементна модель; б) верхня проекція напруженого стану;

в) нижня проекція напруженого стану; г) деформований стан

Далі були проведені роботи, визначені та згруповані у блоці 2 алгоритму (рис. 1). В результаті таких робіт з'ясовано, що для верхнього горизонтального поясу стіни торцевої мінімальний запас міцності

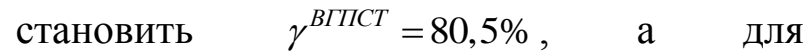
вертикального шворневого стояка стіни

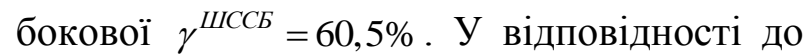
етапу 3.1 (рис.1) визначені допустимі значення моментів опорів для верхнього горизонтального поясу стіни торцевої $\left[W_{X}^{\text {ВППСТ }}\right]=22,92 \mathrm{~cm}^{3}, \quad\left[W_{Z}^{\text {ВГПСТ }}\right]=22,69 \mathrm{~cm}^{3} ; \mathrm{i}$ допустимі значення моментів опорів для шворневої стійки стіни бокової
$\left[W_{Y}^{\text {ШCСБ }}\right]=46,43 \mathrm{~cm}^{3} ; \quad\left[W_{X}^{\text {ШCCБ }}\right]=45,96 \mathrm{~cm}^{3}$.

При цьому у розрахунках як початкові моменти опору, відповідно до ГОСТ5267.6-90, обрано наведені у таблиці значення: $W_{X(Y)}^{\text {nоч. }}=117,54 \mathrm{~cm}^{3} ; W_{Z(X)}^{\text {nоч. }}=116,35 \mathrm{~cm}^{3}$.

Після вищенаведених робіт відповідно до поставлених задач були визначені математичні моделі, які описують зміну його основних показників від варіювання геометричних параметрів (залежності 10-12), особливості таких робіт подано у [8]. Як такі моделі (формули 1012) використовуються шестифакторні узагальнені математичні моделі.

\begin{tabular}{|c|c|c|c|c|c|c|c|c|c|}
\hline $\begin{array}{c}\text { Виконання } \\
\text { вагонного стояка }\end{array}$ & $\begin{array}{c}\mathrm{S} 1, \\
\text { мм }\end{array}$ & $\begin{array}{c}\mathrm{S} 2, \\
\text { мм }\end{array}$ & $\begin{array}{c}\mathrm{S} 3, \\
\text { мм }\end{array}$ & $\begin{array}{c}\mathrm{S} 4, \\
\mathrm{MM}\end{array}$ & $\begin{array}{c}\mathrm{S} 5, \\
\mathrm{MM}\end{array}$ & $\begin{array}{c}\mathrm{S} 6, \\
\mathrm{MM}\end{array}$ & $\begin{array}{c}\mathrm{W}_{\mathrm{X}(\mathrm{Y}),} \\
\mathrm{cm}^{3}\end{array}$ & $\begin{array}{c}\mathrm{W}_{\mathrm{Z}(\mathrm{X}),} \\
\mathrm{cm}^{3}\end{array}$ & $\begin{array}{c}\mathrm{m}_{\text {пог, }} \\
\text { кг }\end{array}$ \\
\hline $\begin{array}{c}\text { Відповідно до ГОСТ } \\
5267.6-90 \text { (рис. 3, а) }\end{array}$ & 9 & 7 & 13 & 13 & 7 & 9 & 117,54 & 116,35 & 28,71 \\
\hline $\begin{array}{c}\text { 3 накладкою 7 мм } \\
\text { (рис. 3, б) }\end{array}$ & 9 & 7 & 20 & 20 & 7 & 9 & 148,59 & 119,39 & 33,24 \\
\hline $\begin{array}{c}\text { 3 імітацією корозійно- } \\
\text { го зносу по ділянках } \\
S 1, \text { S2, S3 (рис. 3, в) }\end{array}$ & 5 & 5 & 5 & 13 & 7 & 9 & 86,99 & 76,74 & 22,12 \\
\hline
\end{tabular}




$$
\begin{aligned}
& W_{X(Y)}=f(S 1, S 2, S 3, S 4, S 5, S 6)=94,52+13,3 S 1+2,35 S 2+1,76 S 3+0,04 S 4+2,37 S 5+ \\
& +11,44 S 6-8,46 S 1^{2}-3,69 S 2^{2}-1,33 S 3^{2}-1,36 S 4^{2}-3,69 S 5^{2}-8,44 S 6^{2}-4,85 S 1 S 2+ \\
& +2,44 S 1 S 3-2,43 S 1 S 4-1,39 S 1 S 5+7,23 S 1 S 6-1,26 S 2 S 3+1,39 S 2 S 4+2,16 S 2 S 5+ \\
& \quad+0,69 S 2 S 6+0,07 S 3 S 4-0,47 S 3 S 4+1,5 S 3 S 4+0,59 S 4 S 5-1,5 S 4 S 6-2,47 S 5 S 6 ; \\
& W_{Z(X)}=f(S 1, S 2, S 3, S 4, S 5, S 6)=-29,77+3,82 S 1+5,56 S 2+2,96 S 3+3,74 S 4+5,56 S 5+ \\
& +1,79 S 6-0,16 S 1^{2}-0,28 S 2^{2}-0,16 S 3^{2}-0,15 S 4^{2}-0,28 S 5^{2}-0,16 S 6^{2}-0,14 S 1 S 2+ \\
& +0,11 S 1 S 3-0,03 S 1 S 4-0,13 S 1 S 5+0,03 S 1 S 6+0,01 S 2 S 3-0,01 S 2 S 4-0,08 S 2 S 5+ \\
& +0,01 S 2 S 6-0,01 S 3 S 4-0,01 S 3 S 4+0,04 S 3 S 4+0,02 S 4 S 5+0,04 S 4 S 6+0,01 S 5 S 6 ; \\
& m_{\text {nог. }}=f(S 1, S 2, S 3, S 4, S 5, S 6)=-7,77+1,37 S 1+1,84 S 2+0,49 S 3+0,74 S 4+1,84 S 5+ \\
& +0,76 S 6-0,04 S 1^{2}-0,09 S 2^{2}-0,02 S 3^{2}-0,02 S 4^{2}-0,09 S 5^{2}-0,04 a_{66} S 6^{2}-0,05 S 1 S 2+ \\
& +0,02 S 1 S 3-0,021 S 4+a_{15} S 1 S 5+0,03 S 1 S 6-0,01 S 2 S 3+0,01 S 2 S 4+0,01 S 2 S 5- \\
& -0,01 S 2 S 6-0,01 S 3 S 4-0,01 S 3 S 4+0,01 S 3 S 4+0,01 S 4 S 5-0,01 S 4 S 6-0,01 S 5 S 6
\end{aligned}
$$

де $\mathrm{W}_{\mathrm{X}(\mathrm{Y})}, \mathrm{W}_{\mathrm{Z}(\mathrm{X})}-$ моменти опору $\mathrm{y}$ відповідних до рис. 2 осях, $\mathrm{cm}^{3}$;

$m_{\text {пог }}-$ погонна маса, кг;

$S_{1}-S_{6}$ - товщини перерізу (див. рис. 3) вагонного стояка (змінні, які варіюються).

Далі 3 урахуванням визначених та поданих у таблиці показників визначені такі резерви міцності (випадок 3б):

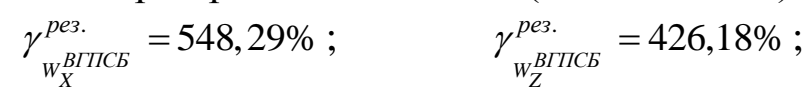

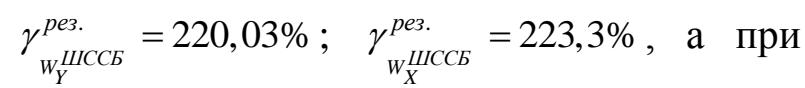
визначенні запасів отримані такі резуль-

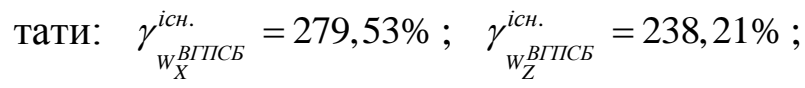

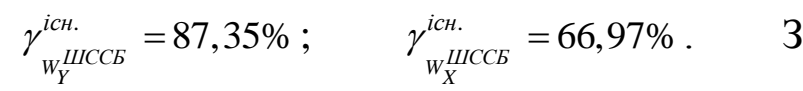
отриманих результатів видно, що при відносно незначному (на 15,8 \%) підвищенні матеріалоємності значно (на $21 \%$ покращується ключове значення моменту опору з відповідним створенням запасів міцності. Також отримані результати яскраво свідчать про невикористані резерви конструкцій кузовів напіввагонів.

Висновки i рекомендації щодо подальшого використання. Приклади використання запропонованого та наведеного у статті підходу до оцінювання несучої здатності кузовів та їх елементів вантажних вагонів засвідчили його працездатність та доцільність застосування. Такий підхід може стати основою для розроблення рівноміцністних конструкцій кузовів вантажних вагонів та процедури прийняття рішень щодо можливості їх подальшої експлуатації (необхідності та обсягів ремонту).

Формалізована процедура визначення запасів міцності складових елементів та загальної конструкції кузовів вантажних вагонів $є$ базовою при проведенні робіт 3 визначення та використання конструкційних резервів при їх проектуванні, а також при визначенні ресурсу (в тому числі залишкового) 3 відповідним прогнозуванням в експлуатації.

Процедуру комплексного дослідження експлуатаційних режимів роботи кузовів вантажних вагонів у подальшому можливо удосконалити (наприклад за рахунок зменшення кількості дослідних випадків) на основі накопиченого досвіду.

Запропонований метод оцінювання несучої здатності металоконструкцій 
кузовів вантажних вагонів можливо застосовувати при проведенні аналогічних досліджень для інших засобів транспортного машинобудування.

\section{Список літератури}

1. Ломотько, Д.В. Современный грузовой подвижной состав нового поколения как приоритетное направление развития украинских железных дорог [Текст] / Д.В. Ломотько // Вагонный парк. - 2012. - № 10(67). - С. 6,7.

2. Фомин, А.В. Формализация процедуры выявления и использования конструкционных резервов грузовых вагонов [Текст] / А.В. Фомин // Научно-теоретический и практический журнал «Оралдың Ғылым жаршысы» (Уральский научный вестник). - 2011. - Вып. № 9(36). - С. 79-82.

3. Горобец, В.Л. Экспериментально-теоретические методы оценки ресурса несущих конструкций подвижного состава железнодорожного транспорта [Текст]: дис. ... д-ра техн. наук; 05.22.07 / В.Л. Горобец; [Днепропетр. нац. ун-т ж. д. трансп. им. акад. В. Лазаряна]. Днепропетровск, 2009. - 304 с.

4. Лукин, В.В. Конструирование и расчет вагонов [Текст]: учеб. для вузов ж.-д. трансп./ В.В.Лукин, Л.А.Шадур, В.Н.Котуранов, А.А.Хохлов, П.С.Анисимов.; под общ. ред. В.В.Лукина. - М.: УМК МПС России, 2000. - 731 с.

5. Котуранов, В.Н. Вагоны. Основы конструирования и экспертизы технических решений [Текст]: учеб. пособие для вузов ж.-д. транспорта / А.П. Азовский, Е.В. Александров, В.В. Кобищанов, В.Н. Котуранов, В.П. Лозбинев, М.Н. Овечников, Б.Н. Покровский, В.И. Светлов, А.А. Юхневский; под ред. В.Н. Котуранова. - М.: Маршрут, 2005. $-490 \mathrm{c}$.

6. Нормы расчета и проектирования вагонов железных дорог МПС колеи 1520 мм (несамоходных) [Текст]. - М.: ГосНИИВ-ВНИИЖТ, 1996. - 354 с.

7. Фомін, О.В.Оптимізаційне проектування елементів кузовів залізничних напіввагонів та організація їх виробництва [Текст]: монографія / О.В. Фомін. - Донецьк: ДонІ3Т УкрДАЗТ, $2013-252$ с.

8. Фомін, О.В. Математичні моделі зміни основних показників базових несучих елементів кузовів напіввагонів [Текст] / О.В. Фомін [та ін.] // Залізничний транспорт України. - К., 2013. - Вип. 8. - С. 52-54.

9. ГОСТ 9.908-85. Методы определения показателей коррозии и коррозионной стойкости. Межгосударственный стандарт [Текст]. - Введ. 01.01.87. - М.: Издательство стандартов, $1999-18 \mathrm{c}$.

10. Полувагоны модели 12-9904 и модели 12-9904-01. Технические условия ТУ У 35.2-30939178-011:2011 [Текст] / разраб. главн. констр. А.В. Фомин; зарегистр. 28.10.2011. в ГП «Донецкстандартметрология». -45 с.

Ключові слова: вантажні вагони, кузов, запаси несучої здатності.

\section{Анотаціiі}

У статті подано метод оцінювання запасів несучої здатності елементів кузовів вантажних вагонів. Формалізовано процедуру визначення запасів міцності складових елементів та загальної конструкції кузовів вантажних вагонів, що є базою при проведенні робіт з визначення та використання конструкційних резервів при їх проектуванні, а також при визначенні ресурсу (в тому числі залишкового) 3 відповідним прогнозуванням в 
експлуатації. Наведено приклади застосування запропонованого підходу при оцінюванні втрати несучої здатності елементів кузовів напіввагонів в експлуатації та покращенні міцнісних якостей при проектуванні.

В статье представлен метод оценивания запасов несущей способности элементов кузовов грузовых вагонов. Формализована процедура определения запасов прочности составных элементов и общей конструкции кузовов грузовых вагонов, которые являются базой при проведении работ по выявлению и использованию конструкционных резервов при их проектировании, а также при определении ресурса (в том числе остаточного) с соответствующим прогнозированием в эксплуатации. Приведены примеры применения предложенного подхода при оценивании потери несущей способности элементов кузовов полувагонов в эксплуатации и улучшении прочностных качеств при проектировании.

The method of evaluation supplies bearing strength of elements baskets freight carriages is presented in the article. Procedure of determination margins of safety component elements and general construction of baskets freight carriages which are a base during the leadthrough of works on an exposure and drawing on construction reserves at their planning formalizovana, and also at determination of resource (including remaining) with the proper prognostication in exploitation. The examples of application offered approach are resulted at the evaluation of loss bearing strength elements of baskets freight gondolas in exploitation and improvement of prochnostnykh qualities at planning. 